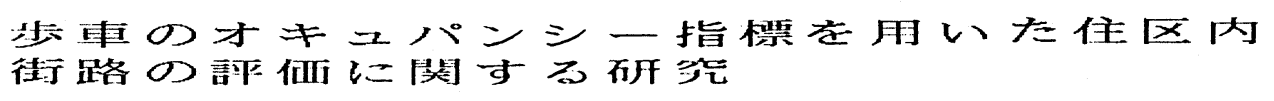

Evaluation of level of service of residential streets based on occupancy concept

塚口博司 黑田英之 $^{* *}$ 矢島敏明 ${ }^{* * *}$ 田中一史 ${ }^{* * * *}$

By Hiroshi Tsukaguchi, Hideyuki Kuroda, Toshiaki Yajima and Kazufumi Tanaka

\begin{abstract}
This paper examines the availavility of the occupancy index of pedestrians cycles, and vehicles, for the planning of residential streets. The models based on the occupancy concept are efficient to discuss not only a condition of a link of residential streets, but also that of residential streets in the area as a whole. Comparing the values of the models and other indices related to a stock of streets, this study proposes a new method to evaluate a level of service of residential streets.
\end{abstract}

1.はじめに

住区内街路は地区住民の生活に密着した生活空間 であり、これを安全・快適でかつ利便性にも富んだ 質の高い空間として整備することは今後の街路計西 において最も重要な課題の一つである。近年、住区 内街路の計画が頻繁に論じられるようになり、また 居住環境整備事業、特定交通安全施設等整備事業等 の各種の事業化手法が設けられるようになった。こ

*正会員 工博 京都大学講師 工学部交通土木 工学教室 (606京都书左京区吉田本唄) **正会員 工修 石川県土木部都市計画課 （920金沢市広坂2-1-1）

***正会員工修住友金属工業 (541 大阪市中 央区北浜4-5-33)

$* * * *$ 正会員 大阪府土木部道路課 (540大阪市中 央区大手前之町)
のように、住区内における街路整備が今後積極的に 行われようとしている今日、住区内街路の現状ある いは住区内街路計画の実施効果等を的確に評価する ことの必要性が一層高まっている。特に、街路の整 備水準に対する評価については、街路を整備する側 だけでなく、住民をはじめとした街路利用者の側に も納得のできるものでなければならず、住区内街路 の整備水準の評価手法の確立が望まれている。

従来より、地区交通計画における評洒については 数多く扱われており、評価モデルも多数提案されて いる”。しかしながら、住区内街路計画を諭じる場 合、評価に関する諸問題は、街路網構成や街路の運 用に関わる代替案の作成方法と並んで依然として検 討すべき最も重要な課題として残っている。さらに、 街路整備水準の評価という観点からみると、幹線道 路に対する議論一般も充分でない現状であり、住区 内街路の整備水準に関する評価は、現在のところほ とんど扱われていない状態である。 
さて、住区内街路に対する評価に関しては、評価 する対象・範团、あるいは評価主体等に刘する吟味 とともに、評価指標や説明指標のあり方についても 再検討を要すると思われる。たとえば、街路の利用 状況を表す指標が街路空間の大きさを表す指標と密 接に結び付いていれば、この指標は街路の運用改善 等を検討する際に便利であると考えられる。

街路空間における各交通手段の街路空間占有の程 度が明らかになれば、自動車、歩行者、自転車とい った異なる交通手段の影響を、空間の占有度という 同じ次元で捉えて評価できる利点がある。さらに、 この場合の指標は空間の大小と密接に関連したもの となっており、上記のような望ましい特徴を備えて いるということができよう。

そこで、本研究では、筆者らがすでに提案した街 路区間における各交通手段の空間占有度を表すオキ ュパンシー指標をまず住区内街路の各街路区間にお ける安全性評価等に適用することにした。次に、オ キュパンシー指標を面的に拡張し、地区レベルで住 区内街路の整備水準を検討する新しい評価方法を提 案した。

\section{2. 住区内街路計西における評価の考え方}

住区内街路計画の一般的な計画手順に沿って考光 ると、評価が必要となる段階は地区診断の段階、代 替案評価の段階、事後評価の段階である。整備水準 評価は地区診断や事業が実施された後の事後評価等 において必要となるものであると考えられ、住区内 街路に対する総合的 な評価と位置づける こともできよう。

評価項目を整理し た上で、住区内街路 計画における評価の プロセスを示すと図 -1のようになろう。 同図では、評価項目 を交通流動の变化に 関係する項目 (B) と、それ以外のより 基本的な項目（C、 D ）に分けてある。
住区内街路計画の実施に伴う交通流動の変化を捉え るのが A - Bの段階での評価である。交通流動ある いはその変化が基本的な評価項目に及ぼす影響を扱 うのが、 $\mathrm{A}-\mathrm{B}-\mathrm{C}$ 評価あるいは一応 $\mathrm{A}$ とは別途 にBーCの関係のみに注目する評侕である。また、 交通量の変化とは直接関係をもたない基本的評価項 目も見逃されがちであるが重要であり、A－Dの段 階で評価がこれに当たる。

さて、本来望ましい評価は基本的な評価項目の段 階で行われるべきであるから、A-B-C、B-C、 $A$-Dといった対応で実施されることが望ましい。 ただし、A-Bの段階での評価も重要である。つま り、住区内街路計画の評価を交通の变化にだけ注目 して行うことは充分ではないが、すべてをC、Dの 段階で的確に評価する手法の開発は決して容易では ないからである。

本論で対象とする評価は図ー1 との関連でみれば、 おおむね B-Cに属するものであり、住区内街路計 画の実施を特に念頭においているわけではない。し かし、これは住区内街路計画にとって不可欠な評価 プロセスである。従来、B-Cに属する評価はお抽 むね交通量等の物的指標を用いて意識指標である外 的基準が説明されていることが多かった。しかし、 自動車交通量だけでなく、路上駐車や他の交通手段 の影響、あるいは街路空間の大きさ等も合理的に取 ク入れることが必要であると思われる。そこで、先 に述べたように各交通手段の空間的な占有度を表す オキュパンシー指標を用いることとした。

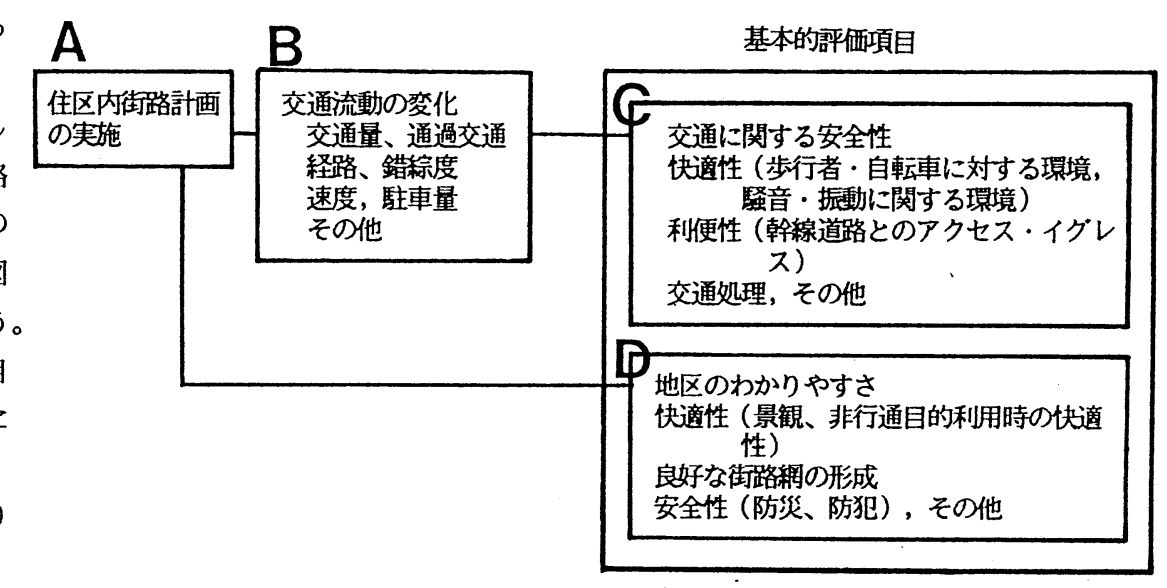

図-1 住区内街路評価の概要 
3. 歩車のオキュパンシー指標

\section{(1) オキュパンシー指標の考え方2}

本論で用いるオキュパンシー指標は住区内街路に おける歩行者 $(p) 、$ 自動車 $(c) 、$ 自転車 $(b)$ 等の空間的 あるいは時間的占有状況を表現するものであり、交 通工学で通常使われているオキュパンシーの概念に 基ついている。まず、住区内のある街路区間 $\mathrm{k} に お ~$ けるオキュパンシーについて考える。本論ではスペ 一スオキュパンシー指標を扱うことにすると、各交 通手段 $i(i=p, c, b) に$ 関するオキュパンシー指標 Qsikは次のように定義される。

$$
\begin{aligned}
\text { Qsik } & =\left(\sum_{j} A i j k\right) /(\boldsymbol{l} k \times d k) \\
& =(q i k \times \bar{A} i k) /(d k \times \bar{v} i k)
\end{aligned}
$$

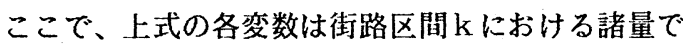
あり、 $\ell k$ は対象とする街路区間長、 d kは街路幅員、 A ijk 恔通手段i の j 番目の交通主体 $i j$ の通行面積、 A $i k$ は手段 $i$ の平均通行面積、 $\bar{v} i k$ は手段 $i$ の平均 速度、qikは交通手段i の交通量である。

オキュパンシー指標は街路区間において各交通手 段が占めている平均的な面積率を表している。才キ ュパンシ一指標のいま一つの特徴は、路上駐車車両 の影響を容易に組み込めることである。路上駐車車 両のオキュパンシー指標は $\mathrm{Qscpk}=(\overline{\mathrm{p}} \mathrm{k} \times \mathrm{Apc}) /$

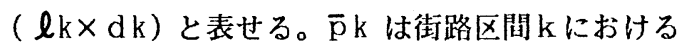
平均瞬間駐車台数、A p c は駐車車両が必要とする面 積である。

オキュパンシー指標は各交通手段別に求めた値を 用いる以外に、各交通手段についてQsik を求め、

Qsik /( Qspk + Qsck + Qsbk) を指標とす ることもできる。これをオキュパンシー構成比と呼 ぶことにする。

\section{（2）オキュパンシー指標の面的搪張}

上記のオキュパンシー指標は街路区間を対象とし たものであるから、これを地区全体に対する評価に 適用するためには、若干の修正が必要となる。そこ で、ここでは各街路区間における各交通手段の空間 占有度を表すオキュパンシー指標 Qsik に当該街路 区間の重みwkを乗じ、これの総和を取ることにより、 地区全体に対する指標とすることにした。ここで、 街路区間 $\mathrm{k}$ の重みとして、 $\mathrm{wk}=($ 街路区間 $\mathrm{k}$ の面積 )/(総街路面積) を用いることにすると、交通手段 iの地区全体に対する面的オキュパンシー指標Qsi
は，次のように表せる。

$$
\begin{aligned}
\mathrm{Qsi}= & \sum_{k}(w \mathrm{k} \times \mathrm{Qsik}) \\
= & 1 / \sum_{k}(\boldsymbol{l k} \times \mathrm{dk}) \\
& \times \sum_{k}(\mathrm{q} i \mathrm{k} \times \boldsymbol{l k} / \overline{\mathrm{v}} \mathrm{ik} \times \overline{\mathrm{A}} \mathrm{ik})
\end{aligned}
$$

また、街路区間に対する指標の場合と同様に、交通 手段 $\mathrm{i}$ の面的オキュパンシー構成比 Qsi／( Qsp+ $\mathrm{Q} s c+\mathrm{Q} s \mathrm{~b})$ を指標とすることもできよう。

Qsiの算出に当たっては、すべての街路区間にお いてQsikを求めることが望ましいであろうが、ここ では、実用性を考虑して幾つかの街路区間を任意抽 出することにした。

\section{（３）必要となるデー夕}

これらのオキュパンシー指標を算出するためには、 (1)自動車の速度と安全通行面積、(2)自転車の速度と 通行面積、(3)歩行者の速度と通行面積、等の諸元を 求めることが必要である。これらの具体的な算出方 法については 文献2）に示すとおりである。本研究 において用いるデー夕は、豊中デー夕（桜塚地区、 庄内地区、緑丘地区、永楽荘地区にて1987年および 1988年実施）、吹田データ（千里山地区にて1988年 実施）、茨木データ（玉瀬地区にて1988年実施）、 寝屋川データ（1985年実施）、および大阪デー夕（ 高倉地区、新森地区、加賀屋地区、鷹合地区にて19 79年および1987年実施）であり、交通量調査、路上 駐車調査、ならびに住民意識調查からなる。

このうち、まず街路区間を対象とした分析には桜 塚、庆内、高倉地区から抽出した合計30の街路区間 のデータを用いた。次に地区レベルでの分析には、 主として桜塚、庄内、緑丘、千里山、玉瀬地区のデ 一夕を用いた。これらの地区では、面的オキュパン シ一指標を求めるために地区全体の $5 \%$ の街路区間 を抽出して基礎調査を行っており、それぞれ20〜50 の区間で街路区間に対するオキュパンシー指標が求 められている。さらに、永楽荘、高倉、加賀屋、鷹 合のデータが用いられている。

\section{（4）オキュパンシー指標の算出事例}

上記の地区におけるオキュパンシー指標の算出事 例を示す。図ー 2 によれば、4種のオキュパンシー 値の和は $0.02 \sim 0.3$ 程度に分布しており、一般に オキュパンシー值の合計が大きい街路においては、 自動車あるいは駐車のオキュパンシーのいずれかが 大きくなっており、両者はトレードオフの関係にあ 
ることが多い。また、歩行者のオキ ュパンシーが相対的にかなり大きい 街路もあり、住区内街路における特 性が表現されている。

本研究では面的なオキュパンシー 指標を求めるに当たって上記のよう に対象地区の街路の $5 \%$ を任意抽出 することにしている。ここで、面的 指標の算出に当たっての精度を若干 調べてみたい。高倉地区に拀いては 全街路区間 (315区間) で交通量等が 測定されている。そこで、このデー

タを用いて $5 \%$ \%サンプリングを10回繰り返して自 動車の面的オキュパンシー指標を求めたところ、平 均と標準偏差はそれぞれ、0.0295，0.0051であり、 変動係数は0.17であった。

4.オキュパンシー指標を用いた街路評仙モデル (1) はじめに

先に述べたように、各交通手段の街路空間におけ る占有の程度を表すオキュパンシー指愠を用いれば、 歩行者、自転車、走行車両、拉よび駐車車両等の街 路空間利用状況を占有度という同じ次元で捉えるこ とができる。そして、このオキュパンシー指標を街 路の安全性等を表す指標と関連付けることができれ ば、有用な評価モデルが構築できると考えられる。 ここでは、このような観点から、まずある街路区間 を対象とした安全性評価および街路に対する住民の 要望度の評価を取扱い、さらに地区全体の街路整備 に関する満足度について検討することにした。

（2）街路区間を対象とした安全性評価モデル

ここでは歩行時の安全性および自転車利用時の安 全性について、各交通手段のスペースオキュパンシ 一指標を説叨变数に册いて評価するモデルを作成す ることにした。

モデルの作成に当たっては、各オキュパンシー指 標をそれぞれ説明変数とする場合と、走行車と駐車 車両のオキュパンシー指標の和を説明変数とする場 合を考えた。後者の場合の指標を駐車車両を考虑し た自動車のオキュパンシー指標と呼ぶことにする。 なお、ここで走行車と駐車車両のオキュパンシー指 標の和を説明変数とするのは、両者はおおむねトレ

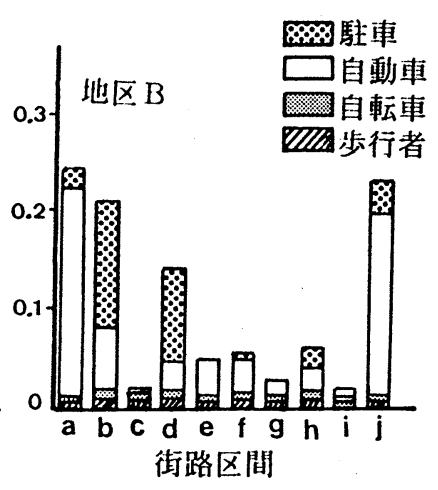

园一2 オキュバンシー指標の算出事例

ードオフの関係にあることが多いからである。一方、 外的基準には危険感を用いることとし、対象とする 街路区間の利用頻度の高い人の歩行時危険感ならび に自転車利用時の危険感（評価値はそれぞれ「やや 危険」と「危険」の構成比の和）を用いる場合と、

「安全」から「危険」までの5 段階評価值の平均值 を用いる場合の 2 通りの方法を用いた。

まず、歩行時危険感 ( S pk) ならびに自転車利用 祢の危険感（S bk）を外的基準とし、自動車、駐車 車両、自転車、歩行者のオキュパンシー指標および 歩道の有無等を説明变数として重回帰分析を行い、 最も適合度の高いモデルとしてそれぞれ次式を得た。 $\mathrm{Spk}=2.0 \mathrm{Qsck}+1.3 \mathrm{Qscpk}+12.7 \mathrm{Qsbk}+4.0$

$$
(r=0.82)
$$

$\mathrm{Sbk}=2.9 \mathrm{Qsck}+1.3 \mathrm{Qscpk}+9.5 \mathrm{Qsbk}+14.7$ (4)

$$
(r=0.88)
$$

ここで用いたデー夕は桜塚、庄内、高倉の各地区で 得られたものであり、合計 300 街路区間を対象とし ている。なお、上式のいずれの変数も有意水準 0.01 で有意である。

以上のモデルの各変数を標準化し、標準偏回帰係 数を表一 1 に示すと、自転車オキュパンシーは自転 表 -1 標準偏回帰係数

\begin{tabular}{l|c|c}
\hline & S pk & S bk \\
\hline Q sck & 0.609 & 0.789 \\
Q scpk & 0.426 & 0.394 \\
Q sbk & 0.430 & 0.288 \\
\hline
\end{tabular}


車利用時の危険感に比較して歩行時の危険感を增大 させる要因となっていることがわかる。また、上式 における自動車 (走行車) のオキュパンシーは路上 駐車のオキュパンシーと比較して、安全性に対する 影響がやや大きくなっている。

次に、駐車車両を考慮した自動車のオキュパンシ 一指標を説明変数とし、安全性評価值 $\mathrm{Sk}$ 外的基 準とすれば、次式が得られる。

$\mathrm{Sk}=0.73-8.2(\mathrm{Qsck}+\mathrm{Qscpk})$

式（5）はすでに、街路区間における交通量および 駐車量の許容量等の検討に有効であることが示され ている3゙。

このように、自動車のオキュパンシー、路上駐車 のオキュパンシー等を用いて、歩行時あるいは自転 車利用時における街路の安全性評価モデルを作成す ることができる。

(3) 街路区間に対する住民の要望度の評価

街路の安全性評価モデルである式（3）、（4） の適用事例として次のようなものが考えられる。

歩行時の危険感と自転車利用時の危険感が街路改 善に対する住民の要望にどの程度関連しているかを 見てみたい。ここでは各街路に対して何らかの対策 を要望する住民の割合を当該街路の対策要望度と呼 ぷことにする。この対策要望度を地区全体にほぼ均 等に分布した住民に対して求め、先に求めた歩行時 危険感と自転車利用時の危険感に当該街路を利用す る頻度が週 1 回以上の住民の割合を乘じたものを説 明変数として次のモデルを得た。

$\mathrm{R}=1.41 \alpha \mathrm{pSpK}+1.25 \alpha \mathrm{bSbK}+8.14$

$$
(\mathrm{r}=0.91)
$$

ここで、 $\alpha \mathrm{p} 、 \alpha \mathrm{b}$ はそれぞれ、徒歩及び自転車によ つて当該街路を週 1 回以上通行する住民の割合であ る。上式を求めるために用いたデー夕は式 (3)、

（4）と同様であり、またいずれの変数も有意水準 0.01 で有意である。

式（3）、（4）、（6）を用いれば、交通量· 駐車量 $\rightarrow$ オュパンシー指標 $\rightarrow$ 危険感評価 $\rightarrow$ 街路整 備に刘する要望 という流れで住民の街路整備に対 する要望の一端を把握することができる。また、モ デル作成に用いたデータの存在する範㘡内で交通量 あるいは駐車量を変化させる場合には、この变化に よって当該街路に対する住民の要望がどの程度变化
するかを調べることができよう。

\section{（4）地区全体の街路整備に関する満足度}

以上で用いたオキュパンシー指標はある街路区間 に対するものであるが、地区レベルに拡張したオキ ユパンシー指標を用いれば、地区全体に対する評価 モデルを以下のように提案できる。

まず、自動車の面的オキュパンシー指標 Qscと街 路整備に関する総合的満足度 S fの関係は図一 3 のよ うに表現でき、式（7）が得られる。

$\mathrm{Sf}=0.17-7.3$ Qsc

次に、歩行者、自動車ならびに自転車の面的なオ キュパンシー指標の和と上記の S fとの関係は図 -4 に示すようであって、式（８）が得られている。

$\mathrm{Sf}=0.23-7.07(\mathrm{Qsp}+\mathrm{Qsc}+\mathrm{Qsb})$

このように、地区全体を対象としても、オキュパ ンシー指標と街路整備に対する満足度とに合理的な 関係を見いだせる。評価指標と説明指標との組合せ は他にも種々あろうが、ここでは次章で街路整備水 準の評価に利用するために、式（7）、（8）を示

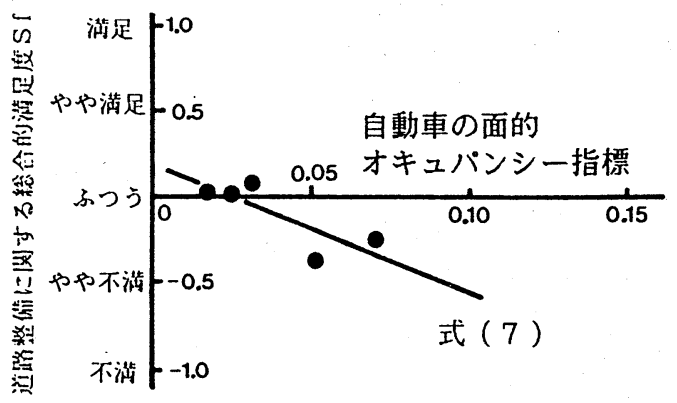

図-3 街路整備に関する淦足度と自動車の 面的オキュパンシー指標

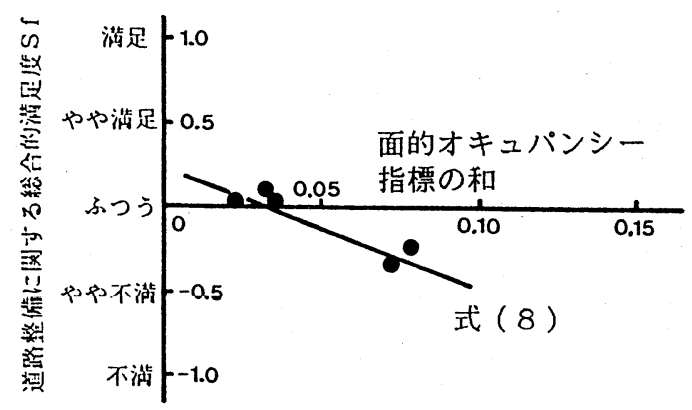

図-4 街路整備に関する㴖足度と面的 オキュパンシー指標の和 
した。

なお、式（7）、（8）はそれぞれ七值が $-3.41 、$ -9.39 であって、式（7）は有意水準0.05で有意で あり、式 ( 8 ) は有意水準 $0.01 て ゙$ 有意である。しか し、以上のモデルは非常に少数の地区デー夕に基づ いていることも事実である。より確実なモデルを得 るためにはさらにデー夕を蓄積する必要がある。

\section{5. 街路整備水準の評価}

\section{（1）基本的な考元方}

幹線道路を中心とした一般道路に㧍ける道路整備 水準は、従来、改良や舗装が済んだか否かを示す状 況指標である改良率、舗装率で表されるか、あるい は道路の機能的な面が充足されているかを示す機能 指標である混雑率およびこれを用いた整備率等によ って表されてきた。さらに、道路の整備内容を実質 的に、また的確に表現するという観点等からよりよ い指標が模索されているのが現状である4”。

一方、住区内街路の整備水準を表す場合には、街 路面積率等の指標が一応の目安にはなるが、これら は安全性・快適性等が重視される住区内街路を対象 として、街路の利用状況を考虑した評価を行うに当 たって利用される指標としては充分でないと思われ る。そこで、本研究では、街路の利用状況を表す面 的オキュパンシー指標とその地区における街路空間 の量を表す街路ストック指標とを対比させることに より、基本的には両者の均衡性を確保するという立 場より、地区の街路整備水準を評価することにした。

本稿では、街路ストック指標として次の 2 つの指 標を設定した。

歩車別ストック構成比 $=\mathrm{Si} / \mathrm{Sa}$

歩車別街路面積率 $=\mathrm{Si} / \mathrm{At}$

ここで、Siは手段ｉに割り当てられた街路面積( i $=p, c, b) 、 S$ a 4 当該地区の総街路面積、At他地区 面積である。なお、本来は、自転車に割り当てられ る空間 Sb を別途求めるべきである。しかし、住区 内街路では自転車の通行空間が通常特定されていな いから、Sb を求めず、歩道等の歩行者系空間を歩 行者と自転車の空間として扱うことにした。自転車 の通行スペースの議論は今後も住区内街路の交通問 題を扱う際の課題の一つである。

また、歩車非分離道路における各交通手段別街路
ストックについては、歩車分離が必要となる目安を 自動車交通量が 30 台/時以上と考文 ${ }^{51}$, 交通量が これ以上の場合にはその街路をすべて自動車の空間 とした。一方、これ以下の場合には、その街路にお ける歩行者と自動車のオキュパンシー比を用いてそ れぞれの交通手段に配分した。

街路の利用状況も考虑して住区内街路の整備水準

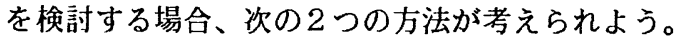
第一は歩車の面的オキュパンシー構成比と歩車別ス トック構成比との比較によって、当該地区における 歩車への街路空間の配分が適切か否かの観点により 評価する方法である。これは土地区画整理事業等に より街路網の基本形態が一応整っている地区の場合 に有効である。第二は歩車の面的オキュパンシー指 標と歩車別街路面積率とを用いる方法であり、これ は街路空間そのものの量が適切か否かの観点により 評価する方法である。この方法は街路網の基本形態 が整っていない地区に対して必要となる検討である。 もっとも、最初に地区特性によってどちらの手法を 用いるべきかを先決するのではなくて、この両者の 評価方法を併せて用いることにより、街路整備水準 を的確に評価することがでさると考える。

(2) 面的オキュパンシー指標と街路ストック指標 を用いた街路整備水準評価手法の提案

a ）既存街路空間の各交通手段への配分の適切性の 検討

図ー 5 は歩行者・自転車に対する面的オキュパン シ一構成比と街路ストック構成比との関係を示した

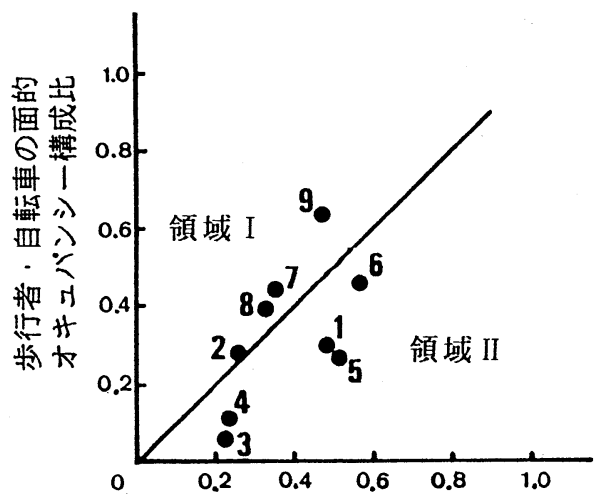

少行者・目転車に対する街路ストック構成比

闵一 5 歩行者・自転車の面的才キュパンシー 㮐成比と街路ストック挴成比 
ものである。なお、自転車については先に述べたよ うに扱い、ここでは图ー5の横軸であるストック棈 成比は $\mathrm{Sp} /(\mathrm{Sp}+\mathrm{Sc})$ と表した。このため、縦 軸も（Qsp+Qsc）/( Q sp+Qsc+Qsb) で表し てある。

同図において、対角線より上の領域 I は、歩行者 および自転車の実際の街路占有の程度が歩行者と自 転車用の街路ストックの割合よりも小さいことを表 しており、歩行者等に対して整備が遅れた地区と言 える。したがって、領域 Iに含まれる地区は整備の 必要性有りと判断できよう。逆に、対角線より下の 領域 II はストック指標がオキュパンシー指標を上回 っており、歩車の空間配分から見ると、歩行者や自 転車に対する整備が進んだ地区であると言えよう。

また、対角線付近に位置する地区は、街路の利用 状況に見合った街路ストックの構成を示しているか ら、街路整備が一応バランスのとれた状態になって いるといえる。これは、もともと住宅地の狭小な街 路空間においては、歩行者等を侵遇するにしても大 幅な空間の配分増は望めず、各交通手段への空間配 分バランスが取れた状態が歩行者交通、自動車交通 のいずれに対しても妥当ではないかとの認識に立つ ている。このように考えると、領域 I に属する地区 は少なくとも対觮付近にまで整借されるべきであ る。もっとも、領域IIに含まれる地区は、バランス の面から見ると歩行者系に偏っているが、住区内街 路の性格を考えると、極端な場合でない限り住区内 街路整備の立場からの問題は少ないと思われる。

図ー5を用いた評価は、街路空間が比較的整備さ
れた地区における歩行者空間整備状況を評価するの に有効と考えられるが、街路空間自体が未整備な地 区に対しては必ずしも有効とは言えないであろう。 このような場合には、次項の評価手法を提案したい。 b ）街路空間の整備量に対する検討

図ー 6 は自動車に対する面的オキュパンシー指標 と自動車空間の面積率との関係を表している。自動 車に対する面的オキュパンー指標Qscは図ー3に示 すように、街路整備に関する総合的満足度と対応関 係がみられる。ここでは、街路整備に対する住民の 当面の総合的満足度の目安として「ふつう」、つま り式（7）におけるSf=0を採用した。そして、こ れに対応する自動車の面的オキュパンシー指標Q sc の值を面的オキュパンシーの許容值と考えることに した。ただし、Sfの值についてはさらに高い水準を 選んでも差し支えない。また、自動車に対する街路 面積率については、便宜的に対象とした地区の平均 を用いて 2 段階に区分した。

図ー6において、領域 $\mathrm{C} 1 、 \mathrm{C} 2$ に含まれる地区は 面的オキュパンシーが許容值を下回っており、街路 整備水準は一応良好と判断できる。ただし、領域 C2 に含まれる地区は自動車に対する街路ストック が極端に少ないために、自動車のオキュパンシーが 小さい地区が含まれている場合があることに注意を 要する。もっとも、自動車空間がやや狭小であって も、防災性等に問題がない場合には、一概に街路整 備水準に問題があるとは言えない。

一方、領域 $\mathrm{A}$ ・領域 Bにはなんらかの対策が必要 であると考えられよう。領域 Bは街路量がかなり多

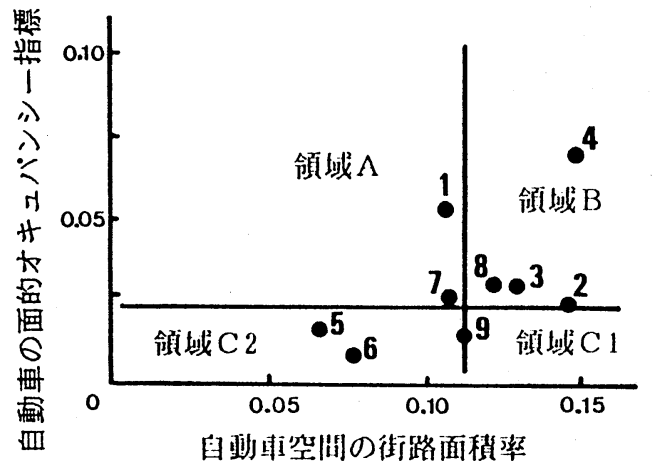

図-6 自動東の面的オキュパンシー指僄 と自動本空焩の街路面䅡率
䓛

$\begin{array}{cc}\text { 图-7 } & 3 \text { 交通手段のオキュバンシーの和と } \\ \text { 街路面積率 }\end{array}$ 
いから、交通運用方法の改善もしくは、街路空間内 の物的施設整借によって交通量の抑制等の刘策が必 要であり、領域C1への移行が望まれる。領城 Aは 街路量そのものが不足しており、整備の方向として は、領域Bに対する整備に加えて、街路空間の拡大 が肝要であろう。

以上では、自動車の面的オキュパンシーと自動車 空間の街路面積率を用いたが、歩行者・自転車の面 的オキュパンシーを用いることも考えられる。また、 次のように地区全体の街路面積率と 3 交通手段の才 キュパンシーの和の関係を用いることもできるであ ろう。

図ー7においても図-6と同様に，3交通手段の オキュパンシーの和と街路整備に関する満足度の関 係を表した図ー4を用いて、オキュパンシー值の許 容值を求めた。また、街路面積率については、新開 発地区および土地区画整理事業実施地区における街 路網形態と街路率の関係を調べ、望ましい街路網を 実現できる街路率の目安を $20 \%$ と設定している。図 - 7 においても領域 $\mathrm{c} 1$ あるいは領域 $\mathrm{c} 2$ において 街路面積率が比較的高い領域が目標とされるべきで ある。図ー7は、図-6に比べて横軸の領域を区分 する值の意味が明確になっており、図ー6を補完す るものである。

\section{c）街路整備水準の評価}

以上では、対象地区における歩車への街路空間の 配分が適切か否かの観点により評価する方法と、街 路空間そのものの量が適切か否かの観点により評価 する方法について述べた。住区内街路の整備水準は この両評価手法を併用して行えばよいと考えられる。 つまり、図ー 5 においては対角線付近かあるいは領 域IIに属し、図ー6においては領域C1に属する地 区を住区内街路整備が良好な地区と位置づけること ができよう。また、図ー5で領域 II 、図ー6におい て領域C2 のうちで街路面積率が比較的高い領域に 属する地区も良好な街路整備水準を有する地区と言 えよう。領域 II に属し、領域 C 2 において街路面積 率が低い領域に属する地区でも、緊急車等の通行に 支障がない場合には当該地区の交通パターンが街路 の状況に見合ったものになっていると評価すること もできよう。一方、図ー5で領域 Iに属するか、あ るいは図ー6で領域 $\mathrm{A}$ や領域 Bに属する地区の場合
には、何等かの街路整備が必要であり、それぞれの 問題点に応じて、街路空間の拡大、歩車への空間配 分の見直し、交通量の削減等の対策が必要なことを 示している。

\section{6.まとめ}

本研究は、住区内街路における歩行者、自動車、 および自転車の空間占有の程度を表すオキュパンシ 一指標を住区内の各街路区間の評価に用いることの 有効性を示した。そして、この指標を地区全体の評 価にも適用できるように修正し、地区全体としての 街路整備状況を評価するためのモデルを作成した。 さらに、これを用いて、住区内街路の整備水準を評 価する手法を提案した。

なお、本研究において作成した地区レベルでの評 価モデルは、その有意性が一応確認されているもの の、非常に少数の地区のデータに依存している。こ のため、以上の手法を一層確実なものとするために は、今後対象地区を増やしてモデルを改善すること が望ましく、また評価手法の実用面での適用性を検 封していくことが必要である。

\section{参考文献}

1) たとえば、以下の報告書に評価モデルの事例が 整理されている.

土木学会関西支部共同研究グループ: 生活地区 における交通の規制と運用に関する研究、 1988.3.

2 ) 塚口博司, 毛利正光: 歩車のオキュパンシー指 標の提案と住区内街路計画への適用, 土木学会 論文報告集, 1987.7 .

3) 塚口博司：住区内街路における駐車現象の分析 と街路運用に関する研究, 土木計画学研究・論 文集, No.4, 1986 .

4 ) 加藤晃 : 道路整備水準の評価手法一基本的な考 え方について一，第14回日本道路会議諭文集， 1981.10

5 ）毛利正光, 塚口博司：住区内道路における歩道 整備に関する基礎的研究，土木学会論文報告集, No. $304,1980.12$. 